Acta vet. scand. $1969,10,10-17$.

From the State Veterinary Institute for Virus Research, Lindholm, near Kalvehave, Denmark.

\title{
PORCINE ADENOVIRUSES
}

\section{ISOLATION AND CYTOPATHOGENIC EXAMINATION OF FOUR SEROLOGICAL TYPES}

By

Poul G. Rasmussen

The first report of the isolation of adenovirus from a pig was that of Haig et al. in 1964. The virus was isolated from faeces and was serologically different from many of the common human adenoviruses. In Denmark, six strains have been found in organ material from pigs (Rasmussen 1966). In the USA Kasza (1966) isolated an adenovirus from the brain of a pig with encephalitic symptoms, and in West Germany the virus was demonstrated in tissue culture of pig kidney from a group of animals where up to every tenth kidney was found to be infected (Mahnel \& Bibrack 1966).

The present study deals with virus strains isolated from noninoculated cell cultures or from normal or diseased pigs. It includes a serological classification of strains isolated from organ material and a study of the cytopathogenic effect of the viruses in cell cultures of the kidneys and lungs of pig embryos and of the kidneys of bacon pigs and calves.

\section{MATERIAL AND METHODS}

The cell cultures of embryonic kidneys and lungs and of the kidneys of newly-slaughtered bacon pigs were grown in Hanks BSS with $0.1 \%$ yeast extract, $0.5 \%$ lactalbumin hydrolysate, $10-15 \%$ calf serum and antibiotics. When a confluent monolayer had developed, the medium was renewed with a corresponding medium of Earles BSS, but containing only $1 \%$ calf serum. 
Attempts were made to isolate the virus from the intestinal content of normal pigs, and from the brain, liver, spleen, pancreas, lungs and intestines of young pigs that had died and showed characteristic patho-anatomical processes (Basse 1967). A $10 \%$ suspension of the material was made in $0.1 \mathrm{M}$ phosphate solution. Cell fragments and microbial contamination were removed by centrifugation, after which antibiotics were added. An amount of $0.1-0.2 \mathrm{ml}$ was inoculated into three to five cell cultures. The medium in the inoculated cell cultures was generally renewed after $24-48 \mathrm{hrs}$. and subsequently every sixth day. Microscopy was performed every other day for a period of 12 18 days after inoculation, in order to observe possible cytopathogenic changes. Parallel examination was made on non-inoculated kidney cell cultures.

The infected fluid from cultures showing cytopathogenic changes was purified by shaking with 10-15\% chloroform for ten minutes, and was then centrifuged. From the supernatant a virus clone was produced by means of the limit dilution procedure. The cytopathogenic effect of all such purified isolates was examined by means of various cell systems, with particular emphasis on the presence of intranuclear inclusion bodies. Microscopy for the cytopathogenic effect was made on living cell cultures and on cultures grown on cover slips in Leighton tubes stained with haemalun-eosin, after fixation in methanol.

The isolates were examined with regard to the common precipitating antigen of the adenovirus group by means of an agar gel diffusion test. The antigen employed was an aqueous suspension of the isolate partially purified with the fluorocarbon compound “Arcton 63", according to the method of Pereira \& Valentine (1958). The antibody used was rabbit antiserum against human adenovirus type 5 . If an isolate was resistant to chloroform, if characteristic intranuclear inclusion bodies were seen, and if precipitation bands with antiserum were produced, it was considered that the isolate belonged to the adenovirus group.

The isolates were examined for haemagglutinins. Each dilution from a series of twofold dilutions of the isolates was mixed with equal volumes of a $0.25 \%$ erythrocyte suspension. The mixtures were placed at room temperature for one to two hrs. before the results were read. Erythrocytes from guinea pig, hen, horse, pig and sheep were used.

Serological typing of the isolates was performed by means of 
neutralization tests. Antiserum was prepared from rabbits immunized with one intravenous and one subcutaneous injection of fluorocarbon-treated virus $(2 \mathrm{ml})$. The serum was recovered from the rabbits three to four weeks after the injections. In the neutralization tests, microscopical registration of cytopathogenic changes in the cell culture was concluded on the fifth to seventh day after inoculation of the serum-virus mixture.

\section{RESULTS}

Twelve agents which were resistant to chloroform and which provoked characteristic intranuclear inclusion bodies have been isolated from porcine material since the autumn of 1963. All the agents showed precipitation bands with rabbit antiserum against human adenovirus 5. These findings show that all the strains belong to the adenovirus group.

Five strains (A 53/65, A 937/65, A 344/66, A 385/66, A 990/66) were isolated from young pigs from which autopsy material was inoculated into cell culture from the kidneys of bacon pigs. In one case virus was isolated from the colon and mesenterial lymph gland (A 53/65), in two cases from the central nervous system (A 937/65, A 990/66), and in two cases from the liver (A 344/66, A 385/66). It was sometimes necessary to perform one or two passages of the agent through cell cultures before recognizable cytopathogenic changes could be seen. Two strains (V 189, V 197) were isolated from embryonic kidney cell cultures inoculated with extract of faeces from normal slaughter pigs. Two strains ( $\mathrm{S}$ 9, S 12) were isolated from kidney cell cultures of bacon pigs also inoculated with faeces extract. Three strains ( K 118, K 016, K 315) were isolated from non-inoculated cell cultures of kidneys from bacon pigs. One of these ( $\mathrm{K} \mathrm{016}$ ) was found in seven out of 160 cell cultures produced from the same pool of kidney tissue, while the two others were found in one out of about 20 cell cultures.

Cross neutralization tests between selected prototypes and their antisera revealed four distinct serological types. All other strains from the organ material were neutralized by one of the antisera of these prototypes. The strains isolated from noninoculated cell cultures were not classified serologically (Table 1).

The cytopathological examinations showed that there were three characteristic forms of nuclear changes (designated $a, b$ and $c$ in Fig. 1). 


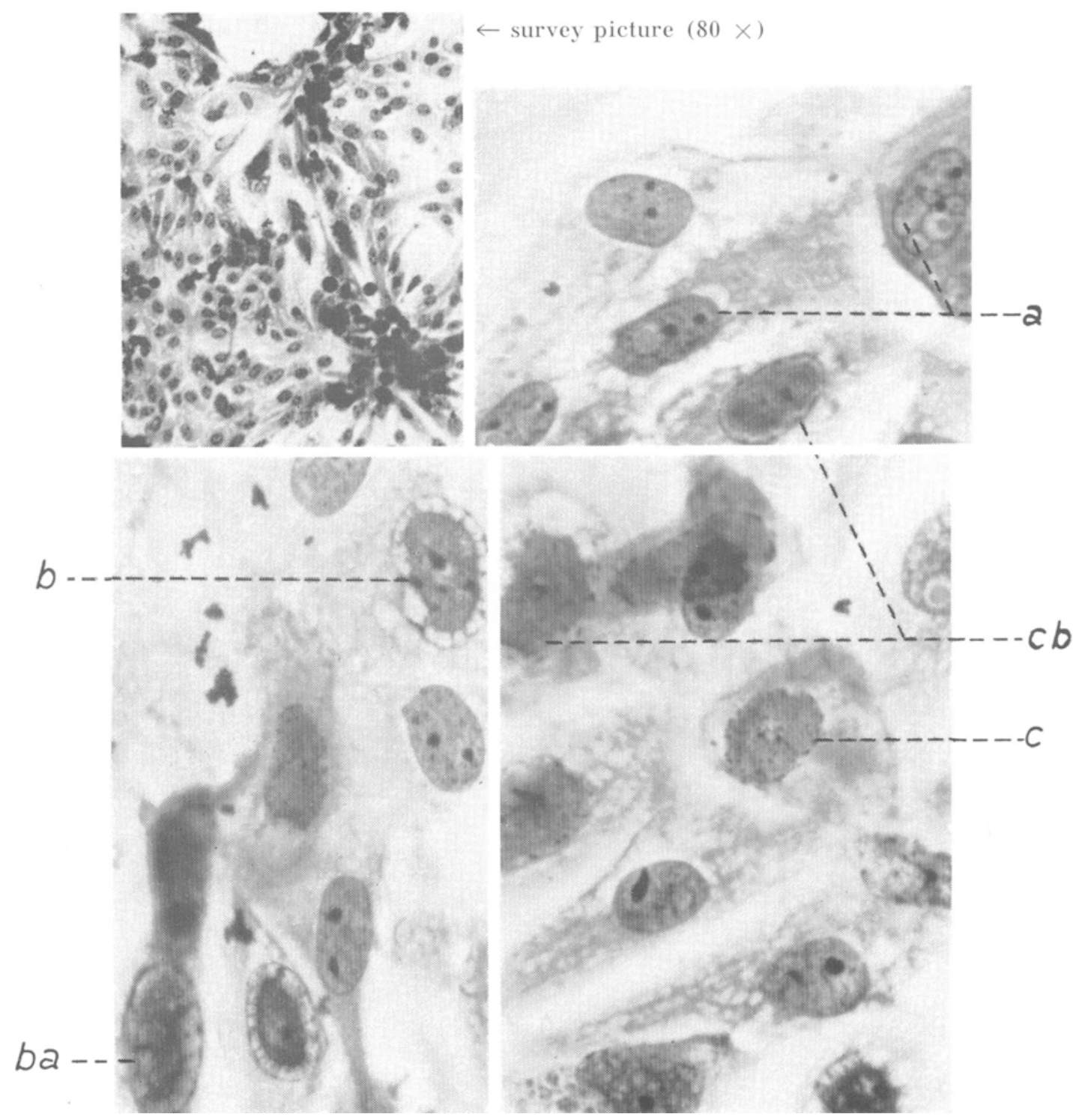

F i g u r e 1. Inclusion bodies induced by porcine adenoviruses inoculated into swine kidney cell culture, haemalun-eosin, x 480 .

a, b, ba, c, cb: lllustrations of the stages of nuclear changes. 

T a ble 1. Cytopathogenic and serological classification of the adenovirus strains.

\begin{tabular}{rll}
\hline $\begin{array}{c}\text { Cytopatho- } \\
\text { genic group }\end{array}$ & $\begin{array}{l}\text { Serological } \\
\text { prototype }\end{array}$ & \multicolumn{1}{c}{$\begin{array}{c}\text { Strains of same } \\
\text { serotype }\end{array}$} \\
\hline I & A $53 / 65$ & A $53 / 65$, A 937 95, A 344 66, A 385/66 \\
I & A $990 / 66$ & A 990/66 \\
II & V 189 & V 189, V 197 \\
III & S 9 & S 9, S 12 \\
III & & $(\mathrm{K} \mathrm{118,} \mathrm{K} \mathrm{016,} \mathrm{K} \mathrm{315)} \mathrm{*}$ \\
\hline
\end{tabular}

* Not studied serologically.

Nuclear change a: The nucleus consisted of normally stained nucleoli and nucleoplasm. However, homogeneous eosinophilic inclusion bodies surrounded by a clear zone were seen in the nucleoplasm. There were generally one to three inclusion bodies, but in some nuclei there were eight to nine.

Nuclear change $b$ : The nucleus consisted of less distinctly stained nucleoli which were in the process of dissolving. The nucleoplasm showed many basophilic granules located centrally; in the periphery a broad clear zone with radial stripes was seen between the granulated mass and the nuclear membrane. There was distinct demarcation between the nuclear membrane and the cytoplasm. Intermediate stages were seen (e.g. nucleus designated ba).

Nuclear change $c$ : The nucleoli had disappeared and the chromatin grains were more distinct and were embedded in a basophilic granulated, heterogeneous nucleoplasm. The demarcation between nucleus and cytoplasm was irregular, without any clear zone or recognizable membrane. There were intermediate stages (e.g. nucleus designated $\mathbf{c b}$ ).

Final stage: The cell formed a compact, basophilic mass with a circular outline. The whole cell was sometimes liberated from the monolayer and had become conglomerated with other degenerated cells (see survey picture of Fig. 1).

These characteristic nuclear changes were caused by all prototypes, independent of the differences in cytopathogenic effect after inoculation in the various cell systems.

The cytopathogenic changes in viable cell cultures were examined daily by microscopy (magnification about $80 \mathrm{x}$ ) for a week or more. Prototypes A 53/65 and A 990/66 (cytopatho- 
genic group I) induced relatively rapid cytopathogenic changes in cell cultures of embryonic tissue and in those of kidneys of bacon pigs. The first cell degeneration was apparent after incubation for three to four days. During the subsequent six to eight days the process spread over the whole monolayer and caused total degeneration. The spread was most rapid in cultures of embryonic cells. Prototypes A 53/65 and A 990/66 caused weak cytopathogenic changes in calf kidney cell cultures in which a few cells with the characteristic inclusion bodies could be seen after incubation for four to six days. The monolayer was otherwise confluent.

Prototype V 189 (cytopathogenic group II) showed distinct affinity to the cell cultures of embryonic tissue and very poor affinity to those of the kidneys of bacon pigs. There was no cytopathogenic effect at all in calf kidney cell cultures. Cytopathogenic processes in the embryonic cells appeared after 48 hrs. and spread to the whole monolayer after further incubation for two days. At that stage small areas of non-degenerated cells could sometimes be seen in the monolayer. Mitosis continued, so that after further incubation for ten days a confluent monolayer had formed in which cytopathogenic changes could not be seen. That phenomenon occurred particularly in cultures of embryonic lung tissue when the medium was changed regularly. However, the embryonic kidney cell cultures generally degenerated completely. When prototype V 189 was inoculated into kidney cell cultures of bacon pigs, it was very difficult to observe any cytopathogenic degeneration whatsoever. This appeared only after incubation for at least six days in the form of large, round cells lying together in an otherwise confluent monolayer. Only a few sporadic cells with typical nuclear changes could be seen in fixed, stained preparations of such cultures.

Prototype S 9 (cytopathogenic group III) and the strains isolated from the non-inoculated kidney cell cultures ( $\mathrm{K}$ strains, Table 1) provoked very weak cytopathogenic effect in cell cultures of embryonic tissue and of kidneys of bacon pigs and calves. Not until after four to six days' incubation visible cellular changes were found, and the process spread slowly over the monolayer. After incubation for ten days, only few vacuolizing infection foci could be seen.

All the strains always attacked the monolayer within the first ten days, even those inoculated in small amounts. The virus 
titres were relatively low ( $10^{1}$ to $\left.10^{3} \mathrm{TCD} 50 / \mathrm{ml}\right)$, except prototype V 189 which gave a higher titre $\left(10^{4}\right.$ to $\left.10^{5} \mathrm{TCD} 50 / \mathrm{ml}\right)$ when propagating in embryonic cells.

Prototype V 189 agglutinated erythrocytes from guinea pig (titre 1:4) and hen (titre $1: 16$ ) but not from horse and pig. Prototypes A 53/65, A 990/66 and S 9 did not agglutinate erythrocytes from guinea pig, hen, horse and pig.

\section{DISCUSSION}

The aim of the study was to present examples of the occurrence of adenoviruses in non-inoculated cell cultures, as well as in normal pigs and pigs that had died of viraemic disease.

The work revealed that porcine adenovirus can be found in the form of latent infection, thus corresponding to what is well known with human adenovirus. This is in accordance with the fact that many animals acquire antibodies against adenovirus, apparently without becoming clinically diseased during such infection (Rasmussen 1966).

Prototype A 53/65 and three other strains of the same serotype were isolated from organ material of pigs belonging to herds where some animals had died. They had shown anorexia, somnolence and slight diarrhoea before death, and generalized viral lesions were found patho-anatomically (Basse 1967). It is true that the strains were isolated from the necropsy material in small amounts only. However, the serological connection and the patho-anatomical findings support the belief that these strains were pathogenic, though continued investigations are necessary to characterize the pathogenicity further.

The nuclear changes found correspond generally to what has been reported previously in HeLa cells infected by human adenovirus (Boyer et al. 1957). Some of the porcine adenovirus provoked more frequently the earlier developing nuclear changes (a and $b$ ) when inoculated into less susceptible tissue cultures, and more of the later nuclear changes (c) when inoculated into more sensitive tissue cultures. The difference in the changes can be explained as the result of different types of cells and viruses. The reason why differentiation cannot be made between the individual types on the basis of the nuclear changes, as in the case of human types, may be due to the heterogeneous cell environment in the primary cell cultures. 
Cell cultures of embryonic lungs and kidneys proved to be the most sensitive for all the strains isolated and are therefore suitable for use in isolating virus from suspected material.

\section{REFERENCES}

Basse, A.: Diseases in pigs caused by adenovirus; pathological-anatomical study. Acta path. microbiol. scand. 1967. Suppl. 187.

Boyer, G. S., C. Leuchtenberger \& H. S. Ginsberg: Cytological and cytochemical studies of HeLa cells infected with adenoviruses. J. exp. Med. 1957, 105, 195-216.

Haig, D. A., M. C. Clarke \& M. S. Pereira: Isolation of an adenovirus from a pig. J. comp. Path. 1964, 74, 81-84.

Kasza, L.: Isolation of an adenovirus from the brain of a pig. Amer. J. vet. Res. 1966, 27, 751-758.

Mahnel, H. \& B. Bibrack: Isolierung von Adenoviren aus Zellkulturen von Nieren normaler Schlachtschweine. (Isolation of adenoviruses from kidney cell cultures of normal slaughter pigs). Zbl. Bakt., I. Abt. Orig. 1966, 199, 329-338.

Pereira, H. G. \& R. C. Valentine: Infectivity titrations and particle counts of adenovirus 5. J. gen. Microbiol. 1958, 19, 178-181.

Rasmussen, P. G.: Unders $\varnothing$ gelser over porcine entero- og adenovirus. (Study of porcine enterovirus and adenovirus). X. Nord. Vet. Congr. Stockholm 1966, 321-325.

\section{SUMMARY}

Since 1963 twelve strains of adenovirus have been isolated in swine kidney cell cultures. Four were isolated from faeces of normal pigs, three from non-inoculated kidney cell cultures, and five from autopsy material from young pigs with patho-anatomical signs of viraemic disease. The strains could be divided into three cytopathogenic groups, which differed in their affinity to cell cultures of embryonic tissue and to cell cultures of the kidneys of bacon pigs and calves. Four serologically different types were found. In susceptible cell cultures, all serological prototypes developed uniform nuclear degeneration of the type characteristic for adenovirus.

\section{ZUSAMMENFASSUNG}

Porcine Adenoviren. Isolierung und cytopathogene Untersuchungen von vier serologischen Typen.

Seit 1963 sind in Zellenkulturen von Schweinenieren 12 Adenovirusstämme isoliert worden und zwar 4 Stämme vom Kot gesunder Schweine, 3 Stämme von nicht-inokulierten Nieren-Zellenkulturen und 5 Stämme von Obduktionsmaterial junger Schweine, die pathologisch anatomisch einen virämischen Zustand zeigten. Die Stämme konnten in 3 cytopathogene Gruppen eingeteilt werden, die mit Bezug auf die 
Affinität zu Zellenkulturen von embryonalem Gewebe, von Niẹren von Baconschweinen und von Kälbern verschieden waren. Es wurden 4 serologisch verschiedene Typen gefunden. In empfänglichen Zellenkulturen entwickelten alle serologische Prototypen einen gleichartigen und für Adenovirus charakteristischen Kerndegenerationsverlauf.

\section{SAMMENDRAG}

Porcine adenovirus. Isolation og cytopatogene undersøgelser af fire serologiske typer.

Siden 1963 er der i cellekulturer fra nyrer af svin blevet isoleret 12 adenovirusstammer. Fire stammer isoleredes fra fæces af sunde svin, tre stammer fra ikke-inokulerede nyrecellekulturer og fem stammer fra obduktionsmateriale af unge grise, der patologisk-anatomisk viste en viræmisk tilstand. Stammerne kunne inddeles i tre cytopatogene grupper, der var forskellige med hensyn til affinitet til cellekulturer fra embryonalt væv, nyrer af baconsvin og kalve. Der fandtes fire serologisk forskellige typer. I modtagelige cellekulturer udviklede alle serologiske prototyper et ensartet og for adenovirus karakteristisk kernedegenerationsforl $\varnothing \mathbf{b}$.

(Received June 25, 1968). 